\title{
Athens, Jerusalem, and Rome: A Reply to Luciano Pellicani
}

\section{Adrian Pabst}

\section{Introduction}

In his polemic against revealed religion, Luciano Pellicani makes two fundamental claims that are historically and philosophically misguided. First, he asserts that the Puritans sought to establish a medieval collectivist theocracy, not a modern market democracy. Second, he maintains that the U.S. "culture war" between enlightened secular liberalism and reactionary religious conservatism ultimately rests on the perpetual battle between Athenian reason and the faith of Jerusalem. Accordingly, Pellicani argues that America's commitment to principles such as individual freedom, religious tolerance, or the constitutionally enshrined separation of Church from State represented Enlightenment emancipation from the constricting shackles of fanatical fundamentalism. Contrary to the zealous fervor of the Puritan Settlers, the Founding Fathers appealed to individualism, rationalism, and even atheism in their opposition to the tyranny of theistic revelation.

That is why — so Pellicani's story goes - Paine, Jefferson, and Madison embraced "[d]eism [which], albeit presenting itself as the "natural religion,' was nothing else but the philosophy of the Enlightenment, based on the primacy of reason and the principle of freedom." Thus, the process of secularization grew out of "the cultural revolution of the Enlightenmenta revolution that was a complete intellectual and moral revolution against the totalitarian dominion Christianity exercised over Westerners." In short, both the U.S. constitution and its political history have revolved around the culture war between the theocratic absolutist order of faith preached 
by the Puritans and the secular democratic order of reason promoted by the Founding Fathers.

In what follows, I shall contest Pellicani's assertion that faith is opposed to reason and that America needs to eschew its Christian heritage in favor of Enlightenment secularism. My contention is that the modern sundering of belief from rationality underpins both secular rationalism and fanatical fideism. The only genuine alternative to these two extremes is not an attempt to repair the wreck that is the Enlightenment project but rather a proper synthesis of faith and reason that distinguishes political from religious authority without divorcing religion from politics. While mainstream Protestantism in the United States is characterized by a vague "civil religion" that is post-Christian and Gnostic in outlook, it is also the case that the rapprochement of Evangelicals and Catholics around shared notions of the common good has the potential to transform the American polity, economy, and society.

\section{Protestantism and Secularization}

Pellicani's essay overstates the difference between the Puritan Settlers and the Founding Fathers. Both are part of a broad Protestant Evangelical tradition that rejects not only "a central ecclesiastical authority" but also the overarching ecclesial and social unity of Christendom, which underpinned the constitutional, political, and socioeconomic organization of society across the West (including the Byzantine Commonwealth centered on Constantinople). ${ }^{1}$ As David Martin has shown, the Protestant schism led to three long waves of secularizing modernization,

beginning in the 1590 s, accelerating from 1790 to 1850 , and renewing the impulse again in the early 1900s. Very loosely these stages correspond to a movement towards a lay, popular and enthusiastic Christianity, culminating in Pentecostal awakenings with a particularly powerful and influential eruption in Los Angeles in 1906. These awakenings were themselves harbingers of global society and their spread corresponded to the movement of lay people around the globe, to South Africa, Norway, Sicily, Korea or the Southern Cone of Latin America. ${ }^{2}$

1. Dmitry Obolensky, The Byzantine Commonwealth: Eastern Europe, 500-1453 (London: Sphere Books, 1974).

2. David Martin, On Secularization: Towards a Revised General Theory (Aldershot: Ashgate, 2005), p. 27. 
As such, the origins and evolution of the Protestant Reformation contained the seeds of secularization in the sense of displacing Catholic and Orthodox Christianity in favor of new lay cultures. Initially these cultures detached religion from statehood, territoriality, and nationhood and also reduced clerical control over the laity. But they were subsequently co-opted by European princes and kings in the late sixteenth- and seventeenth-century "wars of religions," which subordinated faith either to the central sovereign state or the divinely designated nation — or indeed both at once (as in the case of the United States and France).

Moreover, Protestantism's nominalist denial of universals in real things and its voluntarist accentuation of God's absolute divine power had the triple effect of inverting the primacy of good vis-à-vis evil, elevating the will over the intellect, and removing the sacramental mediation between the individual believer and God. ${ }^{3}$ Crucially, the Protestant tradition in general and its Puritan and Calvinist strands in particular linked divine predestination to messianic exceptionalism, which has governed both the U.S. social imaginary (the shining city on the hill) and its foreign policy narrative (the beacon of democracy to all the nations). ${ }^{4}$ In short, Pellicani's distinction of Puritan theocracy and Deist democracy fails to recognize that both are part of the same secular logic, which replaces the mediated universalism of creedal Christianity with the unmediated faith in America's Manifest Destiny. In this sense, Protestantism simultaneously secularizes religion and sacralizes politics. ${ }^{5}$

\section{The Puritan-Calvinist Foundations of Capitalism}

Like Protestantism, the genesis of capitalism is linked to the origins of modernity, to paraphrase Pellicani. ${ }^{6}$ He is certainly right not to equate the entire Protestant tradition with capitalism (as Weber did), but he is

3. For a longer exposition of this argument, see Adrian Pabst, "The Politics of Paradox: Metaphysics beyond 'Political Ontology," Telos 162 (Winter 2012): 99-119.

4. Michael Northcott, An Angel Directs the Storm: Apocalyptic Religion and American Empire (London: I. B. Tauris, 2004); William Pfaff, The Irony of Manifest Destiny: The Tragedy of American Foreign Policy (New York: Walker and Company, 2010).

5. Protestant secularism is compatible with the Evangelical awakening throughout the "long nineteenth century" (ca. 1800-1950) that coincided with a period of wholesale modernization, setting the United States firmly on the path of global hegemony. See Jon Butler, Awash in a Sea of Faith: Christianizing the American People (Cambridge, MA: Harvard UP, 1990); Michael Young, Bearing Witness against Sin: The Evangelical Birth of the American Social Movement (Chicago: Univ. of Chicago Press, 2006).

6. Luciano Pellicani, The Genesis of Capitalism and the Origins of Modernity, trans. James G. Colbert (New York: Telos Press, 1994). 
surely wrong to associate Puritanism with an economic settlement that was collectivist and feudal. On the contrary, most American Puritans and Calvinists sanctified the pursuit of state-sponsored market interest, as R. H. Tawney argued. ${ }^{7}$ Indeed, both the Settlers and the Founding Fathers embraced in different ways the myth that free-market capitalism-under the aegis of a strong central state - really is a divinely instituted economy of salvation. Accordingly the hidden hand is indeed the hand of providence that generally rewards the provident. As such, America's God is neither a personal Trinitarian Creator nor a remote moral deity but instead a providential force that directly recompenses hard work and business success. In his influential book The Social Sources of Denominationalism, Richard Niebuhr makes the important point that Puritanism and Calvinism provide the link between American capitalism and liberalism: there is a "harmony of the Calvinist conception of individual rights and responsibilities with the interests of the middle class" and "Laissez-faire and the spirit of political liberalism have flourished most in countries where the influence of Calvinism was greatest." 8

Arguably, this strand can be traced to late sixteenth- and seventeenthcentury Calvinists and Puritans who built the new world of the Atlantic North. ${ }^{9}$ Numerous Puritan leaders, such as John Cotton, Cotton Mather, and Solomon Stoddard, or American theologians like Jonathan Edwards reinterpreted Christ's passion as a necessary precondition for the restoration of cosmic political and economic justice after the Fall, which takes the form of a liberal polity and a free market - a vision that culminates in the foundation of America's "commercial republic." 10 Thus, the New Jerusalem inaugurated

an economy of atonement and imputed righteousness; an abstract ledger of relationship to God in place of an older mimesis of the inner divine

7. R. H. Tawney, Religion and the Rise of Capitalism, rev. ed. and intro. Adam B. Seligman (1926; New Brunswick, NJ: Transaction, 1998), pp. 79-132.

8. H. Richard Niebuhr, The Social Sources of Denominationalism, repr. (New York: Holt, 1957), pp. 94-95. Cf. William E. Connolly, Capitalism and Christianity, American Style (Durham, NC: Duke UP, 2008), pp. 17-68.

9. See, inter alia, Menna Prestwich, ed., International Calvinism, 1541-1715 (Oxford: Clarendon, 1985); Mark Valeri, "Religion and the Culture of the Market in Early New England," in Peter W. Williams, ed., Perspectives on American Religion and Culture (Oxford: Blackwell, 1999), pp. 92-104.

10. Mark A. Noll, America's God: From Jonathan Edwards to Abraham Lincoln (New York: Oxford UP, 2002), pp. 227-367. 
life. The relationship of imputation to actual status is indeed a kind of religious equivalent of representationalist epistemology: salvific status refers to real outcomes, while the latter only have value in terms of salvific status. Thereby one has a totality of mutual reference yet without any intrinsic relation or participation, such that this referring paradoxically allows the two poles to develop in independence of each other: you can still get saved in the most materially reduced and debauched circumstances imaginable. ${ }^{11}$

By preaching a gospel of prosperity and conflating the elect with the wealthy, Puritans and Calvinists distorted traditional Christianity and aligned Protestantism with a political-economic liberalism that has licensed the pursuit of power and pleasure. ${ }^{12}$

Since unbridled capitalism is remorselessly atomistic and commodifies all human relationships, the nihilistic amorality and criminal corruption of hedonism has led both Puritans and their neoconservative contemporaries to call for more market freedom in order to bring about salvation and at the same time more state authoritarianism in order to police the ensuing social-cultural anarchy. ${ }^{13}$ Worse, the practice of Evangelical religion has itself become increasingly capitalized: the saving of souls is synonymous with the making of profit, and the church is a marketplace wherein souls are traded as commodities. Thus, the human person is a free-trading agent and a commodified subject all at once. In this sense Protestantism really is like market capitalism, not feudal collectivism.

\section{The Post-Christian Outlook of America's “Civil Religion"}

Pellicani's focus on the opposition between Puritan theocracy and Deist democracy seems to blind him to the unifying role of America's "civil religion." "The country's vague "religiosity" is largely governed by a

11. John Milbank, Beyond Secular Order. Faith, Reason, Geopolitics (Oxford: Wiley-Blackwell, 2013), p. 350.

12. Thomas Frank, One Market under God. Extreme Capitalism, Market Populism, and the End of Economic Democracy (New York: Random House, 2000).

13. Thomas Frank, What's the Matter with Kansas: How Neoconservatives Won the Heart of America (New York: Henry Holt, 2005).

14. I have argued this in greater detail elsewhere. See Adrian Pabst, "The Western Paradox: Why the United States is more religious but less Christian than Europe," in Lucian Leustean, ed., Representing Religion in the European Union: Does God Matter? (London: Routledge, 2012), pp. 168-84. 
post-Christian, Gnostic spirituality that bears increasingly little resemblance to creedal Christianity. ${ }^{15}$ Instead of universal Christian festivals that continue to regulate public life in Europe (even in the secular French Republic), the U.S. polity is structured by specifically American holidays. Paradoxically, America's more strongly privatized public sphere opens up a space for a more explicitly politicized and moralized creed that is more fundamental than the rivalry between traditionalist-conservative and progressive-liberal values fuelling the "culture wars." Crucially, America's civil religion feeds on the Manichean moralism taught in many mainstream churches in order to reinforce a sense of national exceptionalism that pervades U.S. politics. The constant appeal since independence to notions such as New Jerusalem, coupled with the promotion of global market democracy as America's mission for the world, reveals a form of modern messianism that nonetheless has roots in medieval millenarianism. From a more traditional Christian perspective, this vision is secular and heretical all at once because to clothe "market-state" power with the spiritual authority of salvation implies that national self-aggrandizement is necessary to secure God's providential plan.

At its most extreme, this has produced a kind of neo-colonial capitalism that eschews personal perfectibility and social improvement (which were key priorities for an earlier tradition of both liberal and neo-orthodox American Protestants) in favor of geoeconomic and geopolitical expansion. The anarchy of national states and transnational markets is seen as the mark of a sinful, fallen world, which is subject to the providential law of "market-state" governance. The violent struggle of the originally elect nation Israel to hold on to its promised land and the similarly violent struggle of the divinely designated America to fulfill its messianic mission are interpreted as signs of the end times. This fusion of primary promise with ultimate apocalypse underscores the non-Trinitarian and non-incarnational outlook of U.S. Protestantism, which underpins America's semi-Gnostic "civil religion" and also appeals to many members of other world faiths. All of which helps account for the tendency of many U.S. Catholics, Jews, and other religious believers to become more like Protestants.

15. Will Herbert, Protestant, Catholic, Jew: An Essay in American Religious Sociology, rev. ed. (New York: Doubleday, 1960); Thomas Luckmann, The Invisible Religion: The Problem of Religion in Modern Society (New York: Macmillan, 1967); Harold Bloom, The American Religion (New York: Simon \& Schuster, 1992); Nancy Ammerman, Congregation and Community (New Brunswick, NJ: Rutgers UP, 1997). 
However, strong Catholic immigration from Central and Latin America might change this in future. Likewise, here are clear indications that the progressive tradition of evangelicals is currently undergoing a significant revival. Large sections of North American evangelicals have sought to transform modern secular politics and economics. Until the First World War and again during the civil rights movement of the late 1950s and the 1960s, they were in fact politically progressive. As Marcia Pally has shown, Evangelicalism was anti-elitist, anti-authoritarian, economically egalitarian (against corporate banking and wealthy landlords), and socially interventionist on behalf of the common good-running social programs for the poor, vastly expanding popular institutions like the U.S. postal service, and providing some of the earliest critique of laissez-faire capitalism. ${ }^{16}$ This all changed in the 1960 s when, partly in response to the Democratic Party's growing secular agenda, both Evangelicals and Catholics embraced the New Right and formed a coalition with the Republicans. ${ }^{17}$ In this process, they endorsed the sort of "small government" politics first promised by Ronald Reagan and nowadays championed by the Tea Party movement.

Currently the United States is witnessing a rapprochement between Evangelicals and Catholics that attempts to re-orient the American Dream away from right-wing market-driven materialism (or the social-democrat alternative of statist welfare) toward greater self-organization of communities and the associative ties of intermediary institutions. Connected with this is the argument that civil society is neither synonymous with commercial exchange nor the same as purely voluntary action but instead represents a more primary realm that is ultimately upheld by the Church. This vision is advanced by a new generation of influential Evangelicals like Jim Wallis and David Platt, whose work resonates strongly with Catholic social teaching and cognate traditions in the Episcopalian Church. ${ }^{18}$

16. Marcia Pally, The "New Evangelicals": Expanding the Vision of the Common Good (Grand Rapids, MI: Wm. B. Eerdmans, 2011).

17. Mark Stricherz, Why the Democrats are Blue: Secular Liberalism and the Decline of the People's Party (New York: Encounter Books, 2007).

18. Jim Wallis, God's Politics: Why the Right Gets It Wrong and the Left Doesn't Get It (New York: HarperCollins, 2005). As a community organizer who was trained in the tradition pioneered by Saul Alinsky, the young Barack Obama worked with local communities and different faith groups to help regenerate Chicago's most deprived inner-city area-a "people's politics" that differs markedly from the collusion of "big government" and "big business" since Nixon. As president, Obama had the opportunity to draw on the 
This, in turn, suggests that Protestant secularization is neither unilinear nor irreversible but itself a dialectical process that oscillates between a dominant secularism, which is positively correlated with modernization, on the one hand, and a more traditional orthodox faith, which challenges the secular orientation of modernity, on the other hand. ${ }^{19}$

\section{IV. "What has Athens to do with Jerusalem?"}

Pellicani's assertion that supernatural faith is opposed to natural reason is just as misguided as the claim that only the Enlightenment can save us from religious fundamentalism. Curiously the logic of Pellicani's position is all too Protestant in its dualistic divorce of rationality from belief. For it was the Reformation's separation of natural immanence and supernatural transcendence that sundered faith from reason and accordingly impoverished both. The former was either "positivized" as an inner impulse or "transcendentalized" as a blind, irrational creed. Likewise, the latter was either enthroned as the sole transcendental absolute or reduced to the positivist rationality of calculus and scientific experimentation. Instead of securing their respective specificity and integrity, this secular conception pitted belief and reasoning against one another. The ensuing opposition between fideism and rationalism fueled the clash of religious fundamentalism and secular fanaticism that has characterized politics and international relations for much of the nineteen, the twentieth, and the early twenty-first centuries. $^{20}$

Without each other's import, both belief and rationality can be distorted and instrumentalized at the service of market individualism or state collectivism - or a sinister fusion of both at once. As Pope Benedict XVI has argued, "distortions of religion arise when insufficient attention is given to the purifying and structuring role of reason within religion";

new rapprochement between Catholics and Evangelicals in order to advance an agenda that is both economically egalitarian and socially transformative. At the time of writing, however, this vision remains wholly unrealized.

19. See Adrian Pabst, "The Paradox of Faith: Religion beyond Secularization and Desecularization," in Craig Calhoun and Georgi M. Derlugian, eds., The Deepening Crisis: Governance Challenges after Neoliberalism (New York: NYU Press/SSRC, 2011), pp. 157-82.

20. See, inter alia, Mark Juergensmeyer, The New Cold War? Religious Nationalism Confronts the Secular State (Berkeley: Univ. of California Press, 1993); Benjamin Barber, Jihad vs. McWorld (New York: Times Book, 1995); John Gray, Al-Qaeda or What it Means to Be Modern (London: Faber, 2003). 
likewise, "without the corrective supplied by religion, though, reason too can fall prey to distortions, as when it is manipulated by ideology, or applied in a partial way that fails to take full account of the dignity of the human person." 21 Just as rationality acts as a controlling organ that binds belief to cognition, so too faith can save reason from being manipulated by ideology or applied in a partial way that ignores the complexity of the real world. Without each other's corrective role, distortions and pathologies arise in both religion and politics. For instance, fanatical believers use faith as a vehicle of hatred and seek to refashion the whole world in their own puritanical image. Likewise, the totalitarian ideologies of the twentieth century were variously more pagan or more atheist, and they legitimated genocide and total warfare in the name of an exceptionalism that was expressed in the language of secularist messianism. The impact of globalization risks exacerbating existing extremes and marginalizing a mediating middle that blends reason with faith.

Ultimately this clash of extremes is the result of de-hellenizing Christianity and other religions such as Judaism and Islam. Hellenization marked the creative encounter and transformative synthesis of Greco-Roman reason with the faith of Jerusalem. Hellenized Judaism sought to universalize the Jewish faith beyond ethnicity and territoriality by building on the prophecy of Isaiah (chapters 40-66) that speaks of a new creation, which has been interpreted as prefiguring the coming of Christ. Here it is instructive to invoke the work of Philo of Alexandria (20 BC-50 AD) who was a contemporary of Jesus and argued for an allegorical interpretation of Scripture that drew on ancient mythology and philosophy - an experience that foreshadowed the "inculturation" of Christianity in pagan societies. ${ }^{22}$ Both Jesus himself and the Apostles were rooted in the Hellenic tradition of Judaism, as were the Apostolic Fathers and the Apologists who viewed Greek and Roman thought as preparatio evangelica. Later, the

21. Pope Benedict XVI, Meeting with the Representatives of British Society, Westminster Hall, September 17, 2010, available online at the Vatican website, http:// www.vatican.va/holy_father/benedict_xvi/speeches/2010/september/documents/ hf_ben-xvi_spe_20100917_societa-civile_en.html.

22. Martin Hengel, Juden, Griechen und Barbaren: Aspekte der Hellenisierung des Judentums in vorchristlicher Zeit (Stuttgart: Katholisches Bibelwerk, 1976); trans. Jews, Greeks and Barbarians: Aspects of the Hellenization of Judaism in the Pre-Christian Period, trans. John Bowden (Philadelphia: Fortress, 1980); Martin Hengel, The 'Hellenization' of Judea in the First Century after Christ, trans. John Bowden (Philadelphia: Trinity, 1989). 
Neo-Platonist Church Fathers and Doctors integrated both Hellenized Judaism and the Greco-Roman tradition into Christianity. They developed a symbiotic relation: just as Christian theology fulfills ancient philosophy, so too ancient philosophy assists Christian "faith seeking understanding"- exploring the paradox of Christ's full divinity and full humanity and making the unknowable mystery of the Incarnation and the Resurrection rationally intelligible. ${ }^{23}$

Of course Pellicani is right to suggest that the conflict between Athens' "culture of reason" and Jerusalem's "culture of faith" is an aspect of Western intellectual history - a well-known thesis for which he cites in support an essay by Leo Strauss on the diametric opposition between rational philosophy and religious prophecy. ${ }^{24}$ It is true that Hellenized Judaism and Hellenic Christianity had many critics. For example, among the Jewish people there were those like the Maccabees and the Zealots who opposed any rapprochement with Hellenism. Likewise, among Christians there were those like Tatian (ca. 110-180) and Tertullian (ca. 160-220) who equated ancient philosophy with unbelief and heresy: "What has Athens to do with Jerusalem?" Tertullian asked provocatively. "Wretched Aristotle," he proclaimed, "God has spoken to us: it is no longer necessary for us to philosophize. Revelation is all that is required. He who merely believes in the word of God knows more than the greatest philosophers have ever known concerning the only matter of vital importance." ${ }^{25}$ However, it is precisely the separation of theology from philosophy that underpins the de-hellenization of Christianity and has fostered the clash between the rationalism of secular extremism and the fideism of fanatical faith. Here

23. The Christianized (Neo-)Platonism of Church Fathers such as Justin, Clement, Origen, Gregory, and Augustine did not simply correct the philosophical and theological errors of Plato (the pre-existence of chaotic matter; the creation of formal order out of material chaos, etc.) and Plotinus (equating matter with absolute evil; the tension between the absolute unity of the One and the plurality of its products; the relation between the One and the metaphysical hierarchy of the world, etc.). Much rather, Christian (Neo-)Platonists modified ancient philosophy precisely in order to develop a Trinitarian theology of creation and incarnation. See Adrian Pabst, Metaphysics: The Creation of Hierarchy (Grand Rapids, MI: Wm. B. Eerdmans, 2012), pp. 54-151.

24. Leo Strauss, "Jerusalem and Athens: Some Introductory Reflections," Commentary 43 (June 1967): 45-57.

25. Tertullian, "De praescriptio haereticorum," in The Ante-Nicene Fathers, vol. 3, Latin Christianity, ed. A. Robertson, J. Donaldson, and A. Cleveland Coxe (1885; New York: Cosimo, 2007), p. 246 (translation modified). 
Pope Benedict's Regensburg address - in which he calls on all religions to integrate faith with reason in new ways such that the world's religious cultures can once more rationally debate their universal beliefs - is far more significant for America and the rest of the West than Leo Strauss's rather drab dualism of the philosopher versus the prophet. ${ }^{26}$

Indeed, the encounter of Greco-Roman philosophy with biblical revelation was not a matter of chance but responded to a common concern with the dual meaning of Logos as both ratio and verbum. The hellenization of both Judaism and Christianity produced a unique synthesis of faith and reason that is the mark of the West. Then as now, the living tradition of catholic-orthodox Christianity provides the conceptual resources for a synthesis that binds together rationality and belief in a mutually corrective and augmenting manner. Faith can reinforce trust in the human capacity for both reasoning and understanding and also trust in the reasonableness of reality. Similarly, "secular" rationality can help religious belief make sense of its claims and give coherence to its intuitions. Crucially, reason and faith can assist each other's search for objective principles and norms that govern personal and political action. What links rationality to belief is the shared commitment to universal standards of truth beyond mere logical coherence and empirical validity. As such, the relationality of reason and faith is not merely a concern for religions but can provide the glue that holds together the polity, the economy, and society.

By expanding the scope of rational cognition, belief allied to rationality celebrates the "grandeur of reason" (Pope Benedict XVI). Accordingly, the re-hellenization of Christianity and other world religions would promote the proper cognitive import of belief. This suggests that faith precedes and exceeds reason, in the sense of a pre-rational trust in the reasonableness of the world that can direct rationality beyond a purely formal, instrumental focus and open it to the possibility of shared ends, which can unite members within and across different polities. Crucially, faith does not necessarily impose a set of dogmatic truths on reason, which would warrant accusations of religious fundamentalism. On the contrary, both faith and reason share a commitment to the quest for truth - faithfully and reasonably.

26. Pope Benedict XVI, The Regensburg Lecture, trans. James V. Schall S.J. (Chicago: St. Augustine's Press, 2007). 


\section{Concluding Remarks: Politics beyond Enlightenment Secularism}

Tocqueville noted that America is at once the freest country in world and the society where there is least of all public debate and most of all tyranny of mass opinion. Over time this has perpetuated the myth of messianic exceptionalism that pervades U.S. politics beyond both the partisan divide and the "culture war" opposing secular liberals to religious conservatives - a tacit consensus that engenders social conformism and a lack of fundamental political choice. By either reducing the common good to individual rights or bracketing the good altogether out of the picture, Enlightenment liberalism is unable to stop the seeming inexorable evolution toward authoritarian democracy and even democratic tyranny. To uphold a genuinely plural universalism requires standards of truth and goodness that can order conflicting values such as freedom, equality, or security.

Instead of abandoning its Christian heritage in favor of secularism, the United States - like the rest of the West - would do well to renew the universal promise of Christianity. Based on the Jewish vision of prophets who call kings to righteousness, the Christian Church embodies the free space between the individual person and the collective state. As the "corporation of corporations," the Church promotes the autonomy of mediating bodies such as monastic orders, parishes, universities, hospitals, guilds, and all kinds of other intermediary institutions that constitute the realm of civil society.

This realm is more primary than either the central state or the free market because it is the space in which individuals and groups form a common civic culture and social bonds that are more fundamental than either formal constitutional-legal rights or economic-contractual ties. The emphasis on participation, reciprocity, and mutuality is connected with a more relational account (in terms of objective - not subjective - rights and reciprocal duties) that outflanks the dialectic of the individual and the collective, which has been dominant since the American and the French Revolution.

By upholding the freedom of all from sovereign coercion, the Church universalizes the ancient idea of free association around shared ends such as the common good and the good life. Even if there are rival visions and contested versions, these and other finalities cannot be reduced to individual rights or entitlements without violating the dignity of the human person because individual rights are collectively defined and centrally 
policed. The distinctly Christian heritage of balancing individual with group rights provides the basis for an "organically" plural universalism that differs from the sinister fusion of moral relativism with political absolutism, which threatens America and the rest of the West.

The shared Christian legacy in East and West rests on the blending of the principle of free association in Germanic law with the Latin sense of equity and participation in the civitas - a unique heritage that gave rise to the notion of constitutional rule and good government (as depicted by Ambrogio Lorenzetti's famous fresco Buon Governo in the Palazzo Pubblico of Siena). All this has the potential to transform America's authoritarian "market-state" into a genuinely liberal polity and market economy. For example, Americans could renew their own best traditions of constitutional rule, a subsidiary federalism that devolves power to the state and municipal levels as well as plural modes of free association, which lie at the heart of its town-hall democracy and market economy. Instead of national exceptionalism, the United States can once again appeal to the principles and practices of embodied universalism that have made it one among many great Christian nations. 